\title{
The Contribution of Genre to Translation Process \& Product: Feature Texts
}

\author{
Nadia Gitya Yulianita1 ${ }^{1}$ Novita Sumarlin Putri ${ }^{2}$ \\ Universitas Jenderal Soedirman ${ }^{1}$, Universitas Sarjanawiyata Tamansiswa ${ }^{2}$ \\ nadiagityay@unsoed.ac.id ${ }^{1}$, novita.sumarlinputri@ustjogja.ac.id ${ }^{2}$
}

Article History: First Received: $31 / 05 / 2020$

Final Revision: $27 / 06 / 2020$

Available online: $30 / 06 / 2020$

\begin{abstract}
This paper aims to investigate how genre is used to help the translator analyze, understand, and translate feature articles from English to Indonesian and the differences in the convention of feature article in other languages. The genre approach is used to give a brief understanding in analyzing the feature article. In this research, the researchers use the ESP (English for Specific Purposes) which sees that genre has the consistency of communicative purpose. Moreover, this research uses parallel texts in the Indonesian version to compare with the English version to know the convention of feature article. The result shows that genre approach, especially ESP, helps the translator overcome the problems in translating feature articles since genre can show the convention, communicative purpose, formulaic expressions, dictions, discourse strategy, discourse community, and discourse markers of the texts. Thus, the translator can find proper translations to fit those criteria.
\end{abstract}

Keywords: Communicative Purpose; ESP; Feature; Genre; Translation.

\section{http://jos.unsoed.ac.id/index.php/jes}

\section{INTRODUCTION}

Translation is an activity to re-contextualize the source text so that it has the closest natural equivalence in terms of meaning and style in the target text (House, 2014; Ran, 2009). In translating texts, genre can be used as a relevant approach in order to meet the closest natural equivalence. Kristina (2014) proposes some reasons why genre can be taken into account when translating a text. First, genre shows the importance of the text structure and why it is created in such a way. Next, it exhibits lexical and grammatical patterns of the language used to create meanings and the organization of the text. Besides, genre implicates the communicative purpose of the text, situational context, target audiences, role and relation between text users, characteristics of textual variations, and role and relations between parallel texts in the target language. Moreover, the understanding of genre can lead us to understand other types of relevant genres with the same genre system. Finally, genre shows how a certain type of text is socially constructed and based on a certain ideology. 
Based on the explanation above, genre can help the translator to organize the text well and find the proper choice of words. Meanwhile, the translator who does not use genre as the approach in translating a particular text may find difficulties in selecting the appropriate diction and constructing the text's convention because sometimes a specific text in the source language may have different convention in the target language, i.e. job application letter and birth certificate.

There are three different approaches in genre studies, namely Systemic Functional Linguistics (SFL), New Rhetoric (NR), and English for Specific Purposes (ESP). SFL sees genre as regularities of staged-goal oriented process while NR focuses on the typical rhetorical action. On the other hand, experts in ESP define genre as "a class of structured communicative events employed by specific discourse communities whose members share broad social purposes" (Swales, 1990). They also believe that genre has the consistency of communicative purposes.

Many researchers had conducted the study about using genre in translation (Albi, 2013; Auria, 2006; Izquierdo \& Albi, 2008; Keresztes, 2013; Orts, 2012; Unger, 2001). Besides, there are researchers who analyzed the news report texts and features using SFL as the genre approach (Choi, 2013; Floros, 2013; Santosa, 2009; Santosa et al., 2011).

From the studies conducted by previous researchers, there are some topics which are left unanalyzed. First, the previous researches have not mainly discussed other types of journalism, especially feature. It is a creative and exclusive story on events, human interest or lifestyle which stands on literature journalism Hennessy (2006:17) and it aims to inform, but it may also narrate, describe, explain, persuade or entertain, and sometimes all five (Hennessy, 2006; Sumadiria, 2006). Second, the ESP approach has not been used in previous researches about journalism articles. Thus, the research about using ESP approach in translating feature articles has not been done yet, whereas many people enjoy reading feature articles or even try to find them in the newspapers or magazines. Since feature articles are usually the readers' favorite in the mass media, this particular genre is chosen as the object of the study. Thus, in this paper the researchers try to find out how genre contributes to the translation process and product, especially in translating feature articles. The choice of words and how the feature writers organize the text based on the specific genre will be analyzed and evaluated in order to produce qualified translation products.

\section{RESEARCH METHOD}

In ESP, the set of communicative purposes is considered as the most reliable determinant of genre membership (Bhatia, 2013; Swales, 1990). It is important to focus on the situational use of the text before analyzing the key features (Hyland, 2007). Besides, genre can be identified by its convention (Bhatia, 2013). Therefore, the researchers conduct the research by analyzing the convention of the feature articles, identifying the communicative purpose of the feature articles, looking at the ways how the communicative purpose is expressed linguistically and what features stood out as a result of their frequency or importance, and finally identifying the position of the communicative purpose.

In other words, after the convention and the communicative purpose of the text is identified, there are five more steps to do in analyzing the particular genre, 
namely: finding the formulaic expressions of the text, collecting specific choice of words, explaining discourse strategy, defining discourse community, and spotting discourse markers. The results from all of those steps should link to the communicative purpose of the text. All of them are also known as microelements in genre. These microelements portray the macro element (genre).

The researchers did those steps to three feature articles in English in order to translate them into Indonesian. Those feature articles with different topics were taken from CNN. The researchers chose the most update topic in May 2020 since this research was conducted in that month. The articles mainly expose the new events happening during the pandemic. The first article is about the hairstyle trend during the pandemic, the second one discusses Michael Jordan's shoes sold in an auction during the pandemic, and the last talks about the new 3D wave in Seoul, Korea. The researchers took different topics from the same online media to find out whether that particular media has the standard convention in writing feature articles.

\section{RESULT AND DISCUSSION}

Genre is "a highly structured and conventionalized communicative event" (Bhatia, 2013). It means that every genre has its own convention which needs to be fulfilled. Feature, as a genre in journalism texts, also has its convention which needs to be maintained by the writers. According to Pape \& Featherstone (2006), feature articles usually start with an intro which contains who and what of the story or even when and where too. Then, the intro is followed by subsequent paragraphs which can be in the form of facts, anecdotes, and quotes. And finally, the feature articles end with a conclusion.

In this paper, the researchers analyze the feature articles from the source texts and parallel texts to see whether features from English have different conventions with features from Indonesia. The researchers use some abbreviations, namely ST which means Source Text (English features) and TT which refers to Target Text (Indonesia features).

Table 1. Convention

\begin{tabular}{|c|c|c|c|}
\hline $\begin{array}{l}\text { Convention } \\
\text { Feature } \\
\text { Article }\end{array}$ & Introduction & $\begin{array}{l}\text { Subsequent } \\
\text { Paragraphs }\end{array}$ & Ending \\
\hline Hairstyle (ST1) & Prologue \& What & Facts, Direct Quotes & Conclusion \\
\hline $\begin{array}{c}\text { Jordan's Shoes } \\
\text { (ST2) }\end{array}$ & Who \& What & Facts, Direct Quotes & $\begin{array}{l}\text { Indirect Quote } \\
\text { (conclusion) }\end{array}$ \\
\hline 3D Wave (ST3) & Prologue \& What & Facts, Direct Quotes & $\begin{array}{l}\text { Indirect Quote } \\
\text { (conclusion) }\end{array}$ \\
\hline Hairstyle (TT1) & Prologue \& What & Facts, Direct Quotes & Conclusion \\
\hline $\begin{array}{c}\text { Jordan's Shoes } \\
\text { (TT2) }\end{array}$ & Who \& What & Facts, Direct Quotes & $\begin{array}{l}\text { Indirect Quote } \\
\text { (conclusion) }\end{array}$ \\
\hline 3D Wave (TT3) & Prologue \& What & Facts, Direct Quotes & $\begin{array}{l}\text { Indirect Quote } \\
\text { (conclusion) }\end{array}$ \\
\hline
\end{tabular}

It can be seen that English and Indonesian features have the same convention. They consist of intro which grabs readers' attention, subsequent paragraphs which 
support the intro, and conclusion which wraps the intro. The subsequent paragraphs of features usually consist of more facts and direct quotes to show authenticity or to support and explain the facts. As for the ending, two features have the conclusion in the form of an indirect quote, while one feature uses a statement.

The difference between the forms of each convention might be because of the different styles of each text. Pape and Featherstone (2006) claim that there are three styles that affect features writing, namely the writer's own style, newspaper's style, and the style of feature. Since feature is a part of soft news which is creatively written, it would not be a problem if the style is different as long as the convention is the same.

Besides the same convention, same genre also shares the same communicative purpose. The feature articles used in this research possess similar communicative purposes since they belong to the same genre. The communicative purposes of those texts are provided in the table below.

Table 2. Communicative Purpose

\begin{tabular}{|c|c|c|c|c|c|}
\hline \multicolumn{3}{|c|}{ English } & \multicolumn{3}{|c|}{ Indonesia } \\
\hline $\begin{array}{l}\text { Hairstyle } \\
\text { (ST1) }\end{array}$ & $\begin{array}{c}\text { Jordan's } \\
\text { Shoes (ST2) }\end{array}$ & $\begin{array}{l}\text { 3D Wave } \\
\text { (ST3) }\end{array}$ & $\begin{array}{l}\text { Hairstyle } \\
\text { (TT1) }\end{array}$ & $\begin{array}{l}\text { Jordan's } \\
\text { Shoes } \\
\text { (TT2) }\end{array}$ & $\begin{array}{l}\text { 3D Wave } \\
\text { (TT3) }\end{array}$ \\
\hline $\begin{array}{l}\text { To inform } \\
\text { the readers } \\
\text { about a new } \\
\text { hairstyle } \\
\text { trend during } \\
\text { pandemic } \\
\text { which is } \\
\text { buzz cut. }\end{array}$ & $\begin{array}{l}\text { To inform the } \\
\text { readers about } \\
\text { the final price } \\
\text { of Michael } \\
\text { Jordan's shoes } \\
\text { in an auction. }\end{array}$ & $\begin{array}{l}\text { To inform } \\
\text { the readers } \\
\text { about a 3D } \\
\text { Wave in } \\
\text { displayed in } \\
\text { a Jumbotron } \\
\text { in Seoul. }\end{array}$ & $\begin{array}{l}\text { To inform } \\
\text { the readers } \\
\text { about a new } \\
\text { hairstyle } \\
\text { trend during } \\
\text { pandemic } \\
\text { which is } \\
\text { buzz cut. }\end{array}$ & $\begin{array}{l}\text { To inform } \\
\text { the readers } \\
\text { about the } \\
\text { final price of } \\
\text { Michael } \\
\text { Jordan's } \\
\text { shoes in an } \\
\text { auction. }\end{array}$ & $\begin{array}{l}\text { To inform } \\
\text { the readers } \\
\text { that there is } \\
\text { a 3D Wave in } \\
\text { displayed in } \\
\text { a Jumbotron } \\
\text { in SM Town } \\
\text { COEX } \\
\text { building. }\end{array}$ \\
\hline
\end{tabular}

The texts tell about something or someone. Feature is different from hard news which delivers the straight and up-to-date news. Meanwhile, feature delivers something or someone from the others' perception. In the analysis above, it is known that all texts analyzed are informing the readers about someone and something. The first text informs a new hairstyle trend during the lockdown and explains the history of this hairstyle. The hairstyle is called a buzz cut. It is a militarystyle which hair is cut so short. This style becomes a trend during the lockdown because some people are worried about their long and untreated hair, so it is better to have their hair cut. Besides, this feature text explains the history of this style which ever became a trend years ago.

The second texts from English and Indonesia inform the readers about Michael Jordan's authentic shoes sold in an auction. These shoes were made specifically for him and they are the only pair of shoes which have different size between the right and left shoe. Moreover, it has Jordan's sign on it. The shoes were sold $\$ 560.000$ or Rp 8.300.000.000, -. 
The following texts tell the readers about a new display in an entertainment building in Seoul, South Korea. The display exposes a giant 3D wave trapped in a giant box. This art shows as if the wave crashes the box. This technology is surely bringing a new atmosphere during the pandemic.

Finally, all texts, English and Indonesia, give information about something new during the situation (pandemic). The first text talks about a new hairstyle, the second one talks about a basketball superstar's shoes sold in an auction, the last one talks about a new installment to bring calmer situation for people facing this pandemic.

Table 3. Formulaic Expressions

\begin{tabular}{cccccc}
\hline \multicolumn{3}{c}{ English } & \multicolumn{3}{c}{ Indonesia } \\
\hline $\begin{array}{c}\text { Hairstyle } \\
\text { (ST1) }\end{array}$ & $\begin{array}{c}\text { Jordan's } \\
\text { Shoes } \\
\text { (ST2) }\end{array}$ & $\begin{array}{c}\text { 3D } \\
\text { Wave } \\
\text { (ST3) }\end{array}$ & $\begin{array}{c}\text { Hairstyle } \\
\text { (TT1) }\end{array}$ & $\begin{array}{c}\text { Jordan's } \\
\text { Shoes } \\
\text { (TT2) }\end{array}$ & 3D Wave (TT3) \\
\hline $\begin{array}{c}\text { Subversive, } \\
\text { here's how, } \\
\text { having a go }\end{array}$ & coincided & $\begin{array}{c}\text { Has } \\
\text { come, } \\
\text { sweeps } \\
\text { over }\end{array}$ & berusaha & Alih-alih & Ada, muncul \\
& & & & \\
\hline
\end{tabular}

Those expressions are the formulaic expressions found in the feature texts. Formulaic expressions mean expressions usually used in a particular text. The word "here's how", "having a go", "sweeps over" are informal expressions and they are very likely to appear in features texts.

In addition, "competed" and "coincided" are used in a feature text explaining the bidders who wanted to get Jordan's sneakers. Besides, "has come" is also used to explain a new thing, not a person. These expressions are used to gain reader's attention so that they want to read the feature articles. Some of these expressions are translated and some are not. This might be because the translators do not recognize this expression as a formulaic expression, but they also add formulaic expression in target texts. The purpose of this addition is also to grab readers' attention to continue reading the feature articles.

Next, the researchers will try to identify the specific choice of words that the writers use in the features. Usually, the writers use these specific words in order to convey some things which are related to the topic and the communicative purpose. Those words are already provided in the following table. 


\begin{tabular}{|c|c|c|c|c|c|}
\hline \multicolumn{3}{|c|}{ English } & \multicolumn{3}{|c|}{ Indonesia } \\
\hline $\begin{array}{l}\text { Hairstyle } \\
\text { (ST1) }\end{array}$ & $\begin{array}{l}\text { Jordan's } \\
\text { Shoes } \\
\text { (ST2) }\end{array}$ & $\begin{array}{l}\text { 3D Wave } \\
\text { (ST3) }\end{array}$ & $\begin{array}{c}\text { Hairstyle } \\
\text { (TT1) }\end{array}$ & $\begin{array}{c}\text { Jordan's } \\
\text { Shoes (TT2) }\end{array}$ & $\begin{array}{l}\text { 3D Wave } \\
\text { (TT3) }\end{array}$ \\
\hline $\begin{array}{c}\text { Lockdown, } \\
\text { Buzz cut, } \\
\text { countercultur } \\
\text { e }\end{array}$ & $\begin{array}{c}\text { Sneakers, } \\
\text { auction } \\
\text { house, } \\
\text { bidder }\end{array}$ & $\begin{array}{c}\text { Wave, LED, } \\
\text { billboard, } \\
\text { digital art, } \\
\text { mused }\end{array}$ & $\begin{array}{l}\text { Lockdown, } \\
\text { karantina, } \\
\text { psbb, buzz } \\
\text { cut, cepak }\end{array}$ & $\begin{array}{l}\text { Sepatu kets, } \\
\text { penyelundup } \\
\text {, penawar }\end{array}$ & $\begin{array}{c}\text { Ombak, } \\
\text { videotron, } \\
\text { seni }\end{array}$ \\
\hline
\end{tabular}

In ST1 there are some repetitions in the word "lockdown" and "buzz cut". The writer repeats these words because it correlates to the communicative purpose which is telling an event about a trend of a hairstyle during the lockdown. Moreover, this repetition is also used to emphasize the topic. Besides, the writer also uses words "counterculture" which explains the trend happening is not a common culture since buzz cut is usually associated to men but now women like this kind of hairstyle too. Meanwhile, ST2 contains more words related to the topic discussed which is Michael Jordan's sneakers and bidding.

On the other hand, the last text has repetitions on the word "wave" and "art" because this 3D wave is a new thing happened in the middle of the city and it can be included in art design since it is unique and beautiful. Thus, the words used in the source texts and target texts are chosen to emphasize the topics and explain the communicative purposes. However, there is a specific word target language which is not suitable in the text. The word "penyelundup" is not suitable in the text context. It might be because the translator did not check his/her translation before publishing the article.

After discussing special choice of words, the researchers try to look at the ST and PT's discourse strategy. Discourse strategy is related to how the writer shows the communicative purpose in the text and organizes it nicely. The discourse strategy from all feature articles can be seen in the following table.

Table 5. Discourse Strategy

\begin{tabular}{|c|c|c|c|c|c|}
\hline \multicolumn{3}{|c|}{ English } & \multicolumn{3}{|c|}{ Indonesia } \\
\hline $\begin{array}{c}\text { Hairstyle } \\
\text { (ST1) }\end{array}$ & $\begin{array}{c}\text { Jordan's } \\
\text { Shoes } \\
\text { (ST2) }\end{array}$ & $\begin{array}{c}\text { 3D Wave } \\
\text { (ST3) }\end{array}$ & $\begin{array}{c}\text { Hairstyle } \\
\text { (TT1) }\end{array}$ & $\begin{array}{c}\text { Jordan's } \\
\text { Shoes } \\
\text { (TT2) }\end{array}$ & $\begin{array}{c}\text { 3D Wave } \\
\text { (TT3) }\end{array}$ \\
\hline $\begin{array}{l}\text { Informing } \\
\text { the new } \\
\text { trend of } \\
\text { haircut } \\
\text { because } \\
\text { people are } \\
\text { worried } \\
\text { about their } \\
\text { hair during }\end{array}$ & $\begin{array}{l}\text { Revealing } \\
\text { the price } \\
\text { of } \\
\text { Michael } \\
\text { Jordan's } \\
\text { signature } \\
\text { shoes in } \\
\text { an } \\
\text { auction. }\end{array}$ & $\begin{array}{c}\text { Describing } \\
\text { the new } \\
\text { digital art } \\
\text { in Seoul. }\end{array}$ & $\begin{array}{l}\text { Informing } \\
\text { the new } \\
\text { trend of } \\
\text { haircut } \\
\text { because } \\
\text { people are } \\
\text { worried } \\
\text { about } \\
\text { their hair }\end{array}$ & $\begin{array}{l}\text { Revealing } \\
\text { the price of } \\
\text { Michael } \\
\text { Jordan's } \\
\text { signature } \\
\text { shoes in an } \\
\text { auction }\end{array}$ & $\begin{array}{l}\text { Describing the } \\
\text { new digital art } \\
\text { displayed in } \\
\text { an } \\
\text { entertainment } \\
\text { building. }\end{array}$ \\
\hline
\end{tabular}




\begin{tabular}{cc}
\hline lockdown & during \\
and the & lockdown \\
history of & and the \\
this & history of \\
hairstyle & this \\
& hairstyle \\
\hline
\end{tabular}

It can be seen in the table that ST1 and ST 3 which tell about something only expose the new things. Because of that reason, the paragraphs in the text only show the things which become the main point of the feature articles. Meanwhile, ST2 highlights the personal belonging of a famous person sold in an auction. Paragraphs in ST2 start with the news of the shoes and then discuss about his career. In essence, the the writers' strategy in writing feature articles depends on the type of the feature and the communicative purpose of the features.

Next, the researchers will identify the discourse community of all feature texts. Discourse community is related to the people who recognize and use the text. It means the text producers and text consumers. This community usually affects how the texts are written.

Table 6. Discourse Community

\begin{tabular}{|c|c|c|c|c|c|}
\hline \multicolumn{3}{|c|}{ English } & \multicolumn{3}{|c|}{ Indonesia } \\
\hline $\begin{array}{l}\text { Hairstyle } \\
\text { (ST1) }\end{array}$ & $\begin{array}{c}\text { Jordan's } \\
\text { Shoes (ST2) }\end{array}$ & $\begin{array}{l}\text { 3D Wave } \\
\text { (ST3) }\end{array}$ & $\begin{array}{c}\text { Hairstyle } \\
\text { (TT1) }\end{array}$ & $\begin{array}{c}\text { Jordan's } \\
\text { Shoes (TT2) }\end{array}$ & $\begin{array}{l}\text { 3D Wave } \\
\text { (TT3) }\end{array}$ \\
\hline $\begin{array}{c}\text { Text } \\
\text { Producer: } \\
\text { Marianna } \\
\text { Cerini, a CNN } \\
\text { journalist }\end{array}$ & $\begin{array}{c}\text { Text } \\
\text { Producer: } \\
\text { Leah } \\
\text { Asmelash } \\
\text { Susannah } \\
\text { Cullinane }\end{array}$ & $\begin{array}{c}\text { Text } \\
\text { Producer: } \\
\text { Karina } \\
\text { Tsui, a CNN } \\
\text { journalist }\end{array}$ & $\begin{array}{c}\text { Text } \\
\text { producer: } \\
\text { CNN } \\
\text { Indonesia }\end{array}$ & $\begin{array}{c}\text { Text } \\
\text { producer: } \\
\text { CNN } \\
\text { Indonesia }\end{array}$ & $\begin{array}{c}\text { Text } \\
\text { producer: } \\
\text { CNN } \\
\text { Indonesia }\end{array}$ \\
\hline $\begin{array}{c}\text { Text } \\
\text { Consumer: } \\
\text { Every people } \\
\text { who reads the } \\
\text { article }\end{array}$ & $\begin{array}{c}\text { Text } \\
\text { Consumer: } \\
\text { Every people } \\
\text { who reads } \\
\text { the article }\end{array}$ & $\begin{array}{l}\text { Text } \\
\text { Consumer: } \\
\text { Every } \\
\text { people who } \\
\text { reads the } \\
\text { article }\end{array}$ & $\begin{array}{l}\text { Text } \\
\text { consumer: } \\
\text { Every } \\
\text { people who } \\
\text { reads the } \\
\text { article }\end{array}$ & $\begin{array}{c}\text { Text } \\
\text { consumer: } \\
\text { Every people } \\
\text { who reads the } \\
\text { article }\end{array}$ & $\begin{array}{c}\text { Text } \\
\text { consumer } \\
\text { : Every } \\
\text { people } \\
\text { who reads } \\
\text { the article }\end{array}$ \\
\hline
\end{tabular}

Based on the discourse community, those three writers of source texts have their own style of writing. The writer of ST1 talks about the trend and the history of this trend, while the writer of ST2 explores more on Michael Jordan's profile. Last, the writer of ST3 shows a new art design. Even though their focus is different, there is no judgment from the writers in the articles. It is also one characteristic of features which differs them from editorials and news report.

From those three of ST and three of PT, each of the them writes the feature article to every people who read the article. It means that the feature article can be 
understood by every people because the feature article does not make the readers understand a particular term hardly.

Table 7. Discourse Markers

\begin{tabular}{|c|c|c|c|c|c|}
\hline \multicolumn{3}{|c|}{ English } & \multicolumn{3}{|c|}{ Indonesia } \\
\hline $\begin{array}{l}\text { Hairstyle } \\
\text { (ST1) }\end{array}$ & $\begin{array}{c}\text { Jordan's } \\
\text { Shoes } \\
\text { (ST2) }\end{array}$ & $\begin{array}{c}\text { 3D } \\
\text { Wave } \\
\text { (ST3) }\end{array}$ & $\begin{array}{l}\text { Hairstyle } \\
\text { (TT1) }\end{array}$ & $\begin{array}{c}\text { Jordan's } \\
\text { Shoes (TT2) }\end{array}$ & $\begin{array}{l}\text { 3D Wave } \\
\text { (TT3) }\end{array}$ \\
\hline $\begin{array}{l}\text { As lockdown } \\
\text { continues, in its } \\
\text { straightforward } \\
\text { minimalism, } \\
\text { hence, at a time } \\
\text { when, but, } \\
\text { suddenly, } \\
\text { indeed, then, } \\
\text { yet, and, by } \\
\text { then, among } \\
\text { them, In the } \\
\text { 1990s and } \\
\text { early to mid- } \\
\text { 2000s, at the } \\
\text { same time, } \\
\text { after a short } \\
\text { hiatus, and } \\
\text { once again }\end{array}$ & $\begin{array}{l}\text { before, } \\
\text { following, } \\
\text { and, thus, } \\
\text { also }\end{array}$ & $\begin{array}{c}\text { But, } \\
\text { while, as } \\
\text { if }\end{array}$ & $\begin{array}{c}\text { Ketika } \\
\text { lockdown, } \\
\text { salah satunya } \\
\text { adalah, } \\
\text { dengan pisau } \\
\text { cukur ini, hal } \\
\text { ini membuat, } \\
\text { awalnya, di } \\
\text { negara-negara } \\
\text { AS, Dalam } \\
\text { minimalisnya } \\
\text { yang } \\
\text { sederhana, Di } \\
\text { tahun 60-an, } \\
\text { Kemudian, } \\
\text { pada } \\
\text { pertengahan } \\
\text { 1970-an, di } \\
\text { 1980-an, } \\
\text { Bukan hanya } \\
\text { karena punk, } \\
\text { kini, }\end{array}$ & $\begin{array}{l}\text { Sebelumnya, } \\
\text { bahkan, dan, } \\
\text { dengan } \\
\text { demikian, } \\
\text { Ketika, tetapi }\end{array}$ & $\begin{array}{c}\text { Namun, tak } \\
\text { hanya itu, } \\
\text { kendati } \\
\text { demikian }\end{array}$ \\
\hline
\end{tabular}

In feature, the role of discourse marker is important. The discourse markers help the writer organize the text. The discourse markers also help the readers understand every single sentence or paragraph. The flow of information can be seen through these discourse markers.

From three feature articles in English and three feature articles in Indonesian, each of the feature writers use different discourse marker. In ST1 the writer uses many discourse markers, "as lockdown continues", "in its straightforward minimalism", "hence", "but" and many more. The use of discourse marker "as lockdown continues" in that feature shows a fact that right now the world is experiencing lockdown because of covid-19. The second discourse marker, "in its straightforward minimalism", exposes the nature of buzz cut. Moreover, "hence" shows the conclusion of previous statements. After that, the next discourse marker "but" is used to show contrast. Then, other discourse markers explain the history of the hairstyle. In ST 2 and ST 3 the writers write less discourse markers than ST 1 
because the content of ST 1 is more than the other two. Most of the discourse markers are translated into target language so that the flow of information can be achieved.

From the explanation about what feature article should contain and how the convention of feature article in source texts (English version) and in target texts (Indonesian version), it can be stated that by knowing the convention of feature articles in English version and in Indonesian version is the same. By finding how the convention of feature article in English version and Indonesian version, this research is expected to help the translator when facing translating problems of the feature articles and what the translator should concern of in feature article. For instance, by knowing the communication purpose, the translator can have the same idea about what the article is about. Besides, recognizing the formulaic expressions of feature articles can give the translator insights about expressions usually used in feature articles. Moreover, knowing specific choice of words would make the translator choose the correct diction for the translation which is suitable to the context. Then, knowing the discourse community and discourse marker would also help the translator to know the style of the writer and find equivalent discourse markers in target language to smoothen the flow of information.

\section{CONCLUSION}

From the discussion above, it can be concluded that this genre-based approach in translating features really helps the researchers maintain the communicative purpose of the texts. Moreover, it gives insight to the translators about how to choose appropriate words in the target language. Besides, it helps the translators organize the text based on the acceptable criteria in the target language. This research shows the convention of feature article in English version and in Indonesian version. It expects the readers, especially the translators, know what aspects that should exist in the translation product. Based on the three feature articles in the English version and three feature articles in the Indonesian version, the researchers find out that both articles show the same substances. It means that the translators already did a good job in translating the articles even though there are still some incorrect choices of words in the second article. Hopefully, this research can give new knowledge about genre-based translation and another point of view for translators to translate feature articles from genre-based perspective. In addition, the future researchers can conduct similar researches with different article genres or other genre-based approaches.

\section{REFERENCES}

Albi, A. B. (2013). A genre analysis approach to the study of the translation of court documents. Linguistica Antverpiensia New Series-Themes in Translation Studies, 12, 33-53.

Auria, M. C. P. . (2006). A genre-oriented translation-based instruction to professional communication. Revista de Lenguaspara Fines Específicos, 11(12), 271-290.

Bhatia, V. K. (2013). Analysing Genre: Language Use in Professional Settings. Routledge. http://repositorio.unan.edu.ni/2986/1/5624.pdf 
Choi, G. . (2013). Translating genre of news stories and the correlated grammar inanalysing student translation errors. Meta: Journal Des Traducteurs / Meta: Translators' Journal, 58(2), 373-396.

Floros, G. (2013). News Translation and Translation Ethics in the Cypriot Context. Meta, 57(4), 924-942. https://doi.org/10.7202/1021225ar

Hennessy, B. (2006). Writing feature articles (4th ed.). Focal Press.

House, J. (2014). Translation Quality Assessment. In Translation Quality Assessment. https://doi.org/10.4324/9781315752839

Hyland, K. (2007). Genre pedagogy: Language, literacy and L2 writing instruction. Journal of Second Language Writing, 16, 148-164.

Izquierdo, I. G., \& Albi, A. B. (2008). A multidisciplinary approach to specialized writing and translation using a genre based multilingual corpus of specialized texts. LSP \& Professional Communication, FagsprogogFagkommunikation, An International Journal, 8(1), 1-18.

Keresztes, C. (2013). Genre based teaching of medical translation. JAHR, 4(7), 535543.

Kristina, D. (2014). Raising Awareness on the Advantages of Genre and Multimodality for Translation Purposes: The Case of Promotional Text Genre. Jurnal Penerjemahan, 1(2), 42.

Orts, M. . (2012). A genre-based approach to the translation of private normative texts in legal english and legal spanish. International Journal for the Semiotics of Law - Revue Internationale de Sémiotiquejuridique, 25(3), 317-338.

Pape, S., \& Featherstone, S. (2006). Feature Writing: A Practical Introduction. In Journal of Chemical Information and Modeling. SAGE Publications Ltd. https://doi.org/10.1017/CB09781107415324.004

Ran, S. (2009). Philosophical interpretation on E. A. Nida's definition of translation. Asian Social Sciences, 5(10), 44-47.

Santosa, R. (2009). Genre in media discourse. Journal of Bahasa Sastra Dan Studi Amerika, English Department, 1-23.

Santosa, R., Priyanto, A. D., \& Nuraeni, A. (2011). Genre and Register of Antagonist's Language in Media: An Appraisal Study of Indonesian Newspapers. Kata, 16(1), 23-36. https://doi.org/10.9744/kata.16.1.23-36

Sumadiria, A. . (2006). Jurnalistik Indonesia. Simbiosa Perkasa Media.

Swales, J. M. (1990). Genre analysis: English in academic and research settings. Cambridge University Press.

Unger, C. (2001). Genre and translation. Revista Alicantina de Estudios Ingleses, 14, 297-321. 